\title{
OPTIMALISASI KINERJA KOLOM FRAKSINASI DI PT X
}

\author{
Suharto, Agung Dwi Hasdianto \\ Fakultas Teknik Program Studi Teknik Industri \\ Universitas Tulang Bawang
}

\begin{abstract}
Fractionation column in PT X is a unit of equipment that aims to separate the gas component wherein the composition is primarily a mixture of propylene and propane $C 3$ to $C 4$ mixture. Based on the calculation of the operating data obtained results C3 on product purity level of $98.92 \%$ upper and purity levels of $\mathrm{C} 4$ in the bottom product of $86.27 \%$. From the correlation analysis of process variables on the dependent variable that is used as a parameter optimization are purity levels of $C 3$ in the top products and product purity $C 4$ at the bottom of the results showed that the most significant process variables influence is a bottom temperature and the amount of reflux flow. Of the two variables are then conducted regression analysis to optimize the parameters to obtain the objective function. Based on the results of the objective function obtained optimal condition is a bottom temperature of 108,04oC and reflux amount of 61.44 tons/hour. Then the results obtained purity levels of C3 in the upper part of the product is $99.99 \%$ and purity of C4 at the bottom of the product by $97.00 \%$. Of the economic calculation under optimal conditions fractionation column will be obtained potential profit of $R p$ 44,346,666 /day.
\end{abstract}

Keywords: Optimization, Performance, Fractionation

\section{PENDAHULUAN}

\subsection{Latar Belakang Masalah \\ PT. Perusahaan Gas Negara (Persero)}

Tbk. sebagai perusahaan transportasi gas bumi terkemuka di Indonesia. Dalam mewujudkan visinya sebagai perusahaan kelas dunia, akan mengembangkan usahanya sebagai penyedia gas bumi yang ditransportasikan dalam bentuk Liquid Natural Gas (LNG). Oleh karena itu, visi tersebut harus didukung oleh
SDM-nya yang memiliki pengetahuan mengenai berbagai aspek yang terkait dengan proses pembuatan LNG, penyimpanan, pengangkutan, regasifikasi, hingga siap untuk digunakan konsumen secara aman.

Salah satu perusahaan yang melakukan kegiatan fraksinasi dalam menjalankan kegiatan operasionalnya adalah PT. X di Balongan. Kolom Fraksinasi yang ada di PRU adalah suatu peralatan yang berfungsi untuk memisahkan fraksi 
campuran $\mathrm{C}_{4}$ (butane/butylene) pada bagian bawah dengan fraksi campuran $\mathrm{C}_{3}$ (propan/propylene) pada bagian atas kolom. Selanjutnya, fraksi campuran $\mathrm{C}_{3}$ akan menghasilkan produk propylene sebagai produk akhir yang jumlahnya sesuai dengan kemurnian hasil produk bagian atas kolom fraksinasi dan fraksi campuran $\mathrm{C}_{4}$ akan menghasilkan produk cair sebagai komponen blending dalam pembuatan LPG. Operator dapat melihat hasil dari proses pemisahan faksi pada kolom fraksinasi melalui kemurnian hasil produk bagian atas dan kemurnian hasil produk bawah.

Oleh karena itu, penulis tertarik melakukan penelitian pada kolom fraksinasi untuk mendapatkan kondisi operasi agar kinerja kolom fraksinasi meningkat. Penelitian ini berjudul "Optimalisasi Kinerja Kolom Fraksinasi di PT. X". Penentuan kondisi ini akan sangat berpengaruh terhadap hasil yang diperoleh sehingga menentukan potensi keuntungan yang akan diperoleh oleh PT X. Dengan kondisi operasi yang optimal diharapkan kinerja kolom fraksinasi akan meningkat dan akan diperoleh hasil kemurnian produk bagian atas dan hasil kemurnian produk bagian bawah yang maksimal.

\subsection{Perumusan Masalah}

Perumusan massalah di sini merupakan tahap penentuan fungsi objektif dan penentuan fungsi-fungsi kendala. Fungsi objektif merupakan fungsi yang terbentuk dari hasil analisis regresi. Fungsi objektif inilah yang akan digunakan sebagai dasar penentuan kondisi optimal (optimalisasi).

Setelah ditentukan semua fungsi objektif dan fungsi kendala, dilakukan pengeplotan fungsi pada satu grafik pertidaksamaan. Dengan mengeplotkan fungsi-fungsi tersebut pada satu grafik yang sama, diharapkan akan terbentuk satu daerah layak (feasible region). Area tersebutlah yang merupakan area operable.

Penentuan kondisi yang optimal dilakukan dengan menguji masing-masing koordinat titik sudut feasible region yang terbentuk. Pengujian dilakukan dengan memasukkan nilai titik koordinat sesuai variabel yang bersangkutan ke dalam fungsi objektif. Selanjutnya dibandingkan hasil yang paling optimal di antara titik-titik sudut tersebut dan dijadikan dasar pengambilan kesimpulan.

\subsection{Tujuan Penelitian}

Tujuan dari penelitian ini adalah:

1) Untuk meningkatkan kinerja dari proses pemisahan kolom fraksinasi guna menetapkan kondisi operasi sehingga menghasilkan top produk dengan kadar kemurnian propan/propylene $\left(\mathrm{C}_{3}\right)$ semaksimal mungkin dan bottom produk dengan kadar kemurnian butane/butylene $\left(\mathrm{C}_{4}\right)$ bagian bawah semaksimal mungkin sesuai dengan spesifikasi yang disyaratkan.

2) Juga untuk mengetahui faktor-faktor apa saja yang paling berpengaruh terhadap kondisi operasi kolom fraksinasi di PT X. 


\section{METODOLOGI PENELITIAN}

\subsection{Kerangka Pemikiran Teoritis}

Kerangka pemikiran merupakan model konseptual tentang bagaimana teori berhubungan dengan berbagai faktor. Faktorfaktor ini telah diidentifikasi sebagai masalah yang penting. Kerangka pemikiran yang baik akan menjelaskan secara teoritis hubungan antara variabel yang akan diteliti.

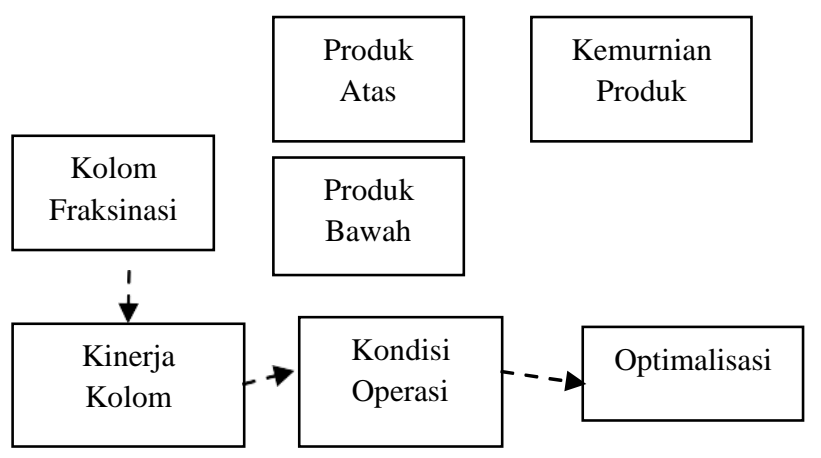

Keterangan :

$\longrightarrow$ Jalur Metodologi Pengumpulan Data

- - $\rightarrow$ Jalur Metodologi Pengolahan Data

\section{Gambar 2.1. Diagram Kerangka Pemikiran Teoritis untuk Penelitian}

Berdasarkan diagram kerangka pemikiran diatas, dapat dilihat bahwa Kemurnian Produk dipengaruhi oleh Produk Atas dan Produk Bawah. Sedangkan Optimalisasi dipengaruhi oleh kondisi operasi. Secara singkat dapat dijelaskan bahwa semakin baik kinerja kolom fraksinasi maka akan semakin banyak kemurnian hasil produk atas yang akan dihasilkan. Akibatnya akan semakin besar Kemurnian Produk dan demikian pula sebaliknya. Pengaruh kinerja kolom fraksinasi terhadap kemurnian produk inilah yang akan dilakukan penelitian dengan metode pengumpulan data.

Untuk mencapai optimalisasi yang diinginkan diperlukan penentuan kondisi operasi yang paling signifikan pada Kolom Fraksinasi. Berdasarkan analisa terhadap kondisi operasi tersebut serta Kemurnian Produk yang diperoleh maka dapat dilakukan analisa Pengolahan Data menggunakan Perhitungan Statistik. Tujuannya untuk mengetahui data kondisi apakah yang paling menentukan Kemurnian Produk yang dihasilkan pada Produk Atas dari Kolom Fraksinasi.

\section{$2.2 \quad$ Hipotesis}

Hipotesis adalah dugaan sementara yang kebenarannya masih harus dilakukan pengujian. Hipotesis ini dimaksudkan untuk memberi arah bagi analisis penelitian. Hipotesis yang diajukan pada penelitian ini adalah " Kemurnian Produk Atas dapat diperoleh $100 \%$ dengan meningkatkan Temperatur pada bagian bawah kolom dan Jumlah Refluks pada bagian atas Kolom Fraksinasi"

\subsection{Variabel Penelitian}

Variabel dalam penelitian dapat diklasifikasikan menjadi :

\subsubsection{Variabel Bebas (Independen)}

Variabel bebas (independen) yaitu variabel yang menjelaskan dan memepengaruhi variabel lain. Variabel independen dalam penelitian ini terdiri dari:

1. Tekanan dibagian atas Kolom (

Pressure Top). 
2. Temperatur Umpan ( Temperature Feed ).

3. Temperatur dibagian atas Kolom (Temperature Top)

4. Temperatur dibagian bawah Kolom (Temperature Bottom)

5. Laju Alir Umpan

6. Jumlah Refluks

\subsubsection{Variabel Terikat (Dependen)}

Variabel terikat (dependen) yaitu variabel yang dijelaskan dan dipengaruhi variabel lain. Variabel dependen dalam penelitian ini adalah :

1. Kemurnian C3 di Top.

2. Kemurnian $\mathrm{C} 4$ di Bottom.

\subsection{Analisa dan Evaluasi Hasil Penelitian}

Data-data variabel independen yang sudah terkumpul kemudian dianalisa kebenarannya. Selanjutnya sesuai kerangka pemikiran teoritis diatas dilakukan tahapantahapan pengolahan data sebagai berikut :

1. Melakukan Pengumpulan Data dimana variabel bebas dan variabel terikat disimulasikan. Hasil akhirnya akan diperoleh hubungan yang paling besar antara variabel bebas dan variabel terikat pada berbagai kondisi operasi.

Di dalam analisis korelasi, dapat diketahui koefisien korelasi antarvariabel. Koefisien korelasi merupakan besaran yang dapat menunjukkan kekuatan hubungan antara dua variabel dan dapat diketahui berdasarkan nilai $\mathrm{r}$ hasil analisis korelasi. Besarnya nilai $r$ dapat diinterpretasi untuk memperkirakan kekuatan hubungan korelasi. Setelah diperoleh pola hubungan antarvariabel dengan analisis korelasi maka selanjutnya dilakukan analisis regresi.

2. Melakukan pengolahan data dengan analisis regresi yaitu menentukan persamaan garis regresi berdasarkan nilai konstanta dan koefisien regresi yang dihasilkan. Kemudian untuk mencari korelasi bersama-sama antara variabel bebas dengan variabel terikat (nilai r).

3. Setelah ditentukan semua fungsi objektif dan fungsi kendala, dilakukan pengeplotan fungsi pada satu grafik pertidaksamaan. Dengan mengeplotkan fungsi-fungsi tersebut pada satu grafik yang sama, diharapkan akan terbentuk

daerah layak (feasible region). Penentuan kondisi yang optimal dilakukan dengan menguji masingmasing koordinat titik sudut feasible region yang terbentuk dan dijadikan dasar pengambilan kesimpulan.

\subsection{Diagram Alir Penelitian}

Berikut ini adalah langkah-langkah yang akan dilakukan dalam penelitian. 


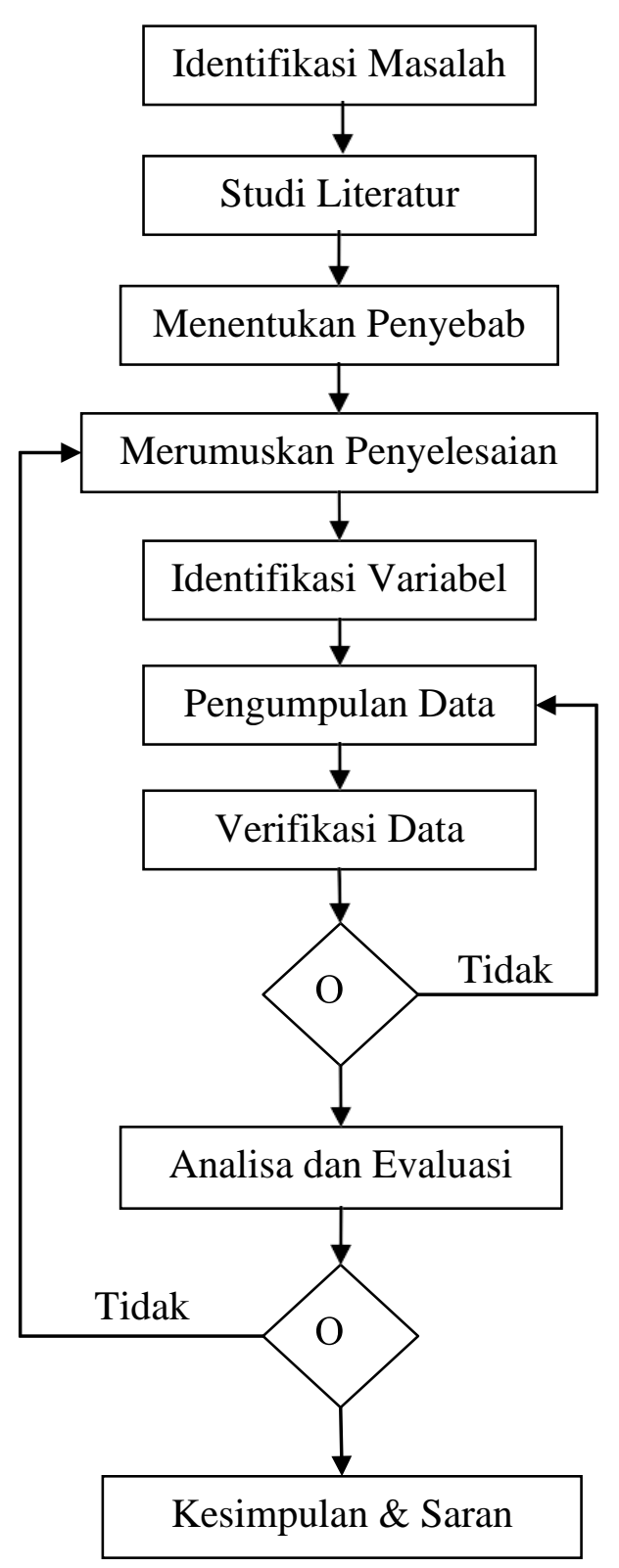

Gambar 2.2. Diagram Alir Penelitian

\section{PEMBAHASAN}

\subsection{Kolom Fraksinasi}

Kolom fraksinasi digunakan untuk memisahkan campuran gas atas komponenkomponennya berdasarkan perbedaan titik didih, selanjutnya fraksi uap yang terpisah pada kondisi tersebut masih merupakan campuran yang komposisinya berbeda dengan komposisi campuran asalnya. Aliran umpan untuk kolom fraksinasi ini memiliki kapasitas 82,77 ton/jam. Data spesifikasi desain kolom fraksinasi adalah sebagai berikut:

- Nama Kolom : $\mathrm{C}_{3} / \mathrm{C}_{4}$

Fraksinasi

- Item : 19-C-

101

- Inside Diameter (mm) : 2600 top/ 3600 bottom

- Operating Pressure $\left(\mathrm{kg} / \mathrm{cm}^{2}\right)$ : 19,74

- Operating Temperatur $\left({ }^{\circ} \mathrm{C}\right) \quad$ : $\quad 49$ Top

/ 109 Bottom

- Desain Temperatur $\left({ }^{\circ} \mathrm{C}\right) \quad: \quad 134$

- Type of tray : Sieve

- Jumlah Tray : 38

- Refluks rasio : $2,9: 1$

- Fluid Description : $\mathrm{H}_{2} \mathrm{O}+$

Hydrocarbon

\subsection{Perhitungan Evaluasi Kolom}

Berikut ini dilakukan evaluasi kolom fraksinasi dengan tahapan-tahapan sebagai berikut. 


\subsubsection{Neraca Massa dan Neraca Komponen}

Tabel 3.2 Berat Molekul Produk Atas

\begin{tabular}{|c|c|c|c|c|}
\hline Komponen & (\% vol) & Yi & BM & Yi.BM \\
\hline $\mathrm{C}_{3}$ & 13,36 & 0,1336 & 44,097 & 5,891 \\
\hline $\mathrm{C}_{3}=$ & 85,56 & 0,8556 & 42,081 & 36,005 \\
\hline $\mathrm{i}^{-} \mathrm{C}_{4}$ & 0,79 & 0,0079 & 58,124 & 0,460 \\
\hline $\mathrm{n}-\mathrm{C}_{4}$ & 0,06 & 0,0006 & 58,124 & 0,035 \\
\hline $1+\mathrm{i}-\mathrm{C}_{4}$ & 0,23 & 0,0023 & 56,128 & 0,128 \\
\hline $\mathrm{Tr}-\mathrm{i}-\mathrm{C}_{4}$ & 0 & 0 & 56,128 & 0,000 \\
\hline Cis- $\mathrm{C}_{4}$ & 0 & 0 & 56,128 & 0,000 \\
\hline & 100 & 1 & & 42,519 \\
\hline
\end{tabular}

Laju alir Produk Atas $\quad$ : $\quad 25,98$ ton $/ \mathrm{jam}=25.977 \mathrm{~kg} / \mathrm{jam}$

Massa Produk Atas (D)

$$
=\frac{25977}{42,519}=610,96 \mathrm{kgmol} / \mathrm{jam}
$$

Hal ini berarti massa yang mengalir pada produk atas setiap jam adalah 610,96 kgmol.

Tabel 3.3 Berat Molekul Produk Bawah

\begin{tabular}{|l|c|c|c|r|}
\hline Komponen & (\% vol) & Yi & BM & Yi.BM \\
\hline $\mathrm{C}_{3}$ & 4,13 & 0,0413 & 44,097 & 1,820 \\
\hline $\mathrm{C}_{3}=$ & 9,50 & 0,095 & 42,081 & 3,997 \\
\hline $\mathrm{i}-\mathrm{C}_{4}$ & 27,50 & 0,275 & 58,124 & 15,983 \\
\hline n- $\mathrm{C}_{4}$ & 6,45 & 0,065 & 58,124 & 3,747 \\
\hline $1+\mathrm{i}-\mathrm{C}_{4}$ & 29,46 & 0,2946 & 56,128 & 16,538 \\
\hline Tr- i-C 4 & 14,49 & 0,1449 & 56,128 & 8,138 \\
\hline Cis-C 4 & 8,47 & 0,0847 & 56,128 & 4,752 \\
\hline & 100 & 1 & & 54,975 \\
\hline
\end{tabular}

Laju alir Produk Bottom : $\quad 31,62$ ton $/ \mathrm{jam}=31623 \mathrm{~kg} / \mathrm{jam}$

Massa Produk Bottom $(B)=\frac{31623}{54,975}=$ $575,23 \mathrm{kgmol} / \mathrm{jam}$
Hal ini berarti massa yang mengalir pada produk bawah setiap jam adalah 575,23 kgmol.

Neraca Massa Umpan $(F)=D+B$

$$
=610,96+
$$

$575,23=1186,19 \mathrm{kgmol} / \mathrm{jam}$

Hal ini berarti massa umpan yang mengalir masuk ke dalam kolom setiap jam adalah $1186,19 \mathrm{kgmol}$.

\begin{tabular}{|c|c|c|c|c|c|c|c|}
\hline \multirow{2}{*}{$\begin{array}{c}\text { Kompo } \\
\text { nen }\end{array}$} & \multicolumn{2}{|c|}{$\begin{array}{l}\text { Produk } \\
\text { Puncak }\end{array}$} & \multicolumn{2}{|c|}{$\begin{array}{l}\text { Produk } \\
\text { Bottom }\end{array}$} & \multicolumn{3}{|c|}{ Umpan } \\
\hline & Yi & $\begin{array}{l}\mathrm{Kg} \\
\mathrm{mol}\end{array}$ & $\mathbf{X i}$ & $\begin{array}{c}\mathrm{Kg} \\
\mathrm{mol}\end{array}$ & $\begin{array}{l}\mathrm{Kg} \\
\mathrm{mol}\end{array}$ & Zi & $\begin{array}{c}\% \\
\text { mol }\end{array}$ \\
\hline 1 & 2 & $\begin{array}{c}3=2 * \\
D\end{array}$ & 4 & $\begin{array}{c}5=4^{*} \\
\mathrm{~B}\end{array}$ & $\begin{array}{c}6=3+ \\
5\end{array}$ & $\begin{array}{c}=6 / \\
F\end{array}$ & $\begin{array}{c}8=7 * \\
100\end{array}$ \\
\hline $\mathrm{C}_{3}(\mathrm{Lk})$ & $\begin{array}{r}0,13 \\
36\end{array}$ & $\begin{array}{r}81,6 \\
2\end{array}$ & $\begin{array}{r}0,04 \\
13\end{array}$ & $\begin{array}{r}23,7 \\
4\end{array}$ & $\begin{array}{r}105, \\
36\end{array}$ & $\begin{array}{r}0,08 \\
88\end{array}$ & 8,88 \\
\hline $\mathrm{C}_{3}=$ & $\begin{array}{r}0,85 \\
56\end{array}$ & $\begin{array}{r}522, \\
75\end{array}$ & $\begin{array}{r}0,09 \\
5\end{array}$ & $\begin{array}{r}54,6 \\
4\end{array}$ & $\begin{array}{r}577, \\
39\end{array}$ & $\begin{array}{r}0,48 \\
68\end{array}$ & 48,67 \\
\hline $\begin{array}{l}\text { i- } \mathrm{C}_{4} \\
(\mathrm{Hk})\end{array}$ & $\begin{array}{r}0,00 \\
79\end{array}$ & 4,83 & $\begin{array}{r}0,27 \\
5\end{array}$ & $\begin{array}{r}158, \\
18\end{array}$ & $\begin{array}{r}163, \\
01\end{array}$ & $\begin{array}{r}0,13 \\
74\end{array}$ & 13,74 \\
\hline $\mathrm{n}-\mathrm{C}_{4}$ & $\begin{array}{r}0,00 \\
06\end{array}$ & 0,37 & $\begin{array}{r}0,06 \\
45\end{array}$ & $\begin{array}{r}37,0 \\
8\end{array}$ & $\begin{array}{r}37,4 \\
5\end{array}$ & $\begin{array}{r}0,03 \\
16\end{array}$ & 3,16 \\
\hline $1+\mathrm{i}-\mathrm{C}_{4}$ & $\begin{array}{r}0,00 \\
23\end{array}$ & 1,39 & $\begin{array}{r}0,29 \\
46\end{array}$ & $\begin{array}{r}169 \\
49\end{array}$ & $\begin{array}{r}170, \\
88\end{array}$ & $\begin{array}{r}0,14 \\
41\end{array}$ & 14,41 \\
\hline Tr- i-C $\mathrm{C}_{4}$ & 0 & 0,00 & $\begin{array}{r}0,14 \\
5\end{array}$ & $\begin{array}{r}83,4 \\
0\end{array}$ & $\begin{array}{r}83,4 \\
0\end{array}$ & $\begin{array}{r}0,07 \\
03\end{array}$ & 7,03 \\
\hline Cis- $\mathrm{C}_{4}$ & 0 & 0,00 & $\begin{array}{r}0,08 \\
47\end{array}$ & $\begin{array}{r}48,7 \\
0\end{array}$ & $\begin{array}{r}48,7 \\
0\end{array}$ & $\begin{array}{r}0,04 \\
11\end{array}$ & 4,11 \\
\hline Jumlah & 1 & $\begin{array}{r}610, \\
96\end{array}$ & 1 & $\begin{array}{r}575 \\
23\end{array}$ & $\begin{array}{r}1186 \\
, 19\end{array}$ & 1 & 100 \\
\hline
\end{tabular}

Tabel 3.4 Neraca Massa Total

Dari tabel diatas didapat massa umpan adalah $1186,19 \mathrm{kgmol} / \mathrm{jam}$

Maka BM umpan adalah $=\frac{62637}{1186,19}=52,805$ $\mathrm{kg} / \mathrm{kgmol}$, hal ini berarti berat molekul umpan yang mengalir masuk ke dalam kolom adalah 52,805.

\subsubsection{Fase Aliran Umpan}

Dari data yang ada temperatur dan tekanan umpan adalah:

Temperatur Umpan $(\mathrm{T}) \quad=63,68{ }^{\circ} \mathrm{C}$

Tekanan kolom

$=\quad 18,43$

$\mathrm{kg} / \mathrm{cm}^{2}=13556,95 \mathrm{mmHg}$ 
Komponen Kunci Ringan (Light Key)

$$
=\mathrm{C}_{3}
$$

Komponen Kunci Berat (Heavy Key)

$$
=\mathrm{i}-\mathrm{C}_{4}
$$

Nilai K (Konstanta Kesetimbangan) dihitung dengan terlebih dahulu menghitung tekanan uap parsial dengan menggunakan konstanta Antoine:

$$
p *=10^{A-\frac{B}{C+T}}
$$

\section{Tabel 3.5 Perhitungan Harga K}

Komponen Umpan

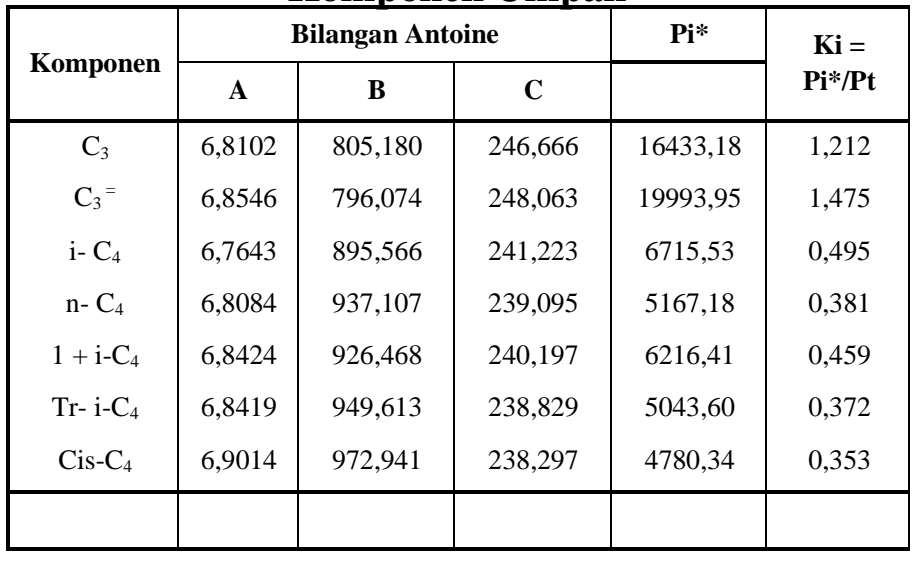

Keterangan :

$\mathrm{P}^{*} \quad=$ Tekanan uap parsial

$\mathrm{T}=$ Temperatur Umpan $=63,68{ }^{\circ} \mathrm{C}$

$\mathrm{Pt}=$ Tekanan parsial $\quad=18,43 \mathrm{~kg} / \mathrm{cm}^{2}$ $=13556,95 \mathrm{mmHg}$

\subsubsection{Yi dan Xi untuk Kondisi Umpan \\ Perhitungan Yi dan Xi untuk} menentukan kondisi umpan dapat dilihat pada table 4.6 di bawah ini.
Tabel 3.6 Perhitungan Menentukan Fase Aliran Umpan

\begin{tabular}{|c|c|c|c|}
\hline Komponen & $\mathbf{Z i}$ & $\mathbf{Y i}=\mathbf{Z i . K i}$ & $\mathbf{X i}=\mathbf{Z i} / \mathbf{K i}$ \\
\hline C3 & 0,0888 & 0,108 & 0,073 \\
\hline C3 $=$ & 0,4868 & 0,718 & 0,330 \\
\hline i- C4 & 0,1374 & 0,068 & 0,277 \\
\hline n- C4 & 0,0316 & 0,012 & 0,083 \\
\hline $1+$ i-C4 & 0,1441 & 0,066 & 0,314 \\
\hline Tr- i-C4 & 0,0703 & 0,026 & 0,189 \\
\hline Cis-C4 & 0,0411 & 0,014 & 0,116 \\
\hline & & 1,012 & 1,383 \\
\hline
\end{tabular}

Dari perhitungan diatas $\sum \mathrm{Yi}=\sum \mathrm{Ki} . \mathrm{Zi}>1$ dan $\sum \mathrm{Xi}=\sum \mathrm{Zi} / \mathrm{Ki}>1$

Jadi kondisi umpan yang masuk ke Kolom Fraksinasi adalah fase dengan kondisi campuran uap dan cair. Kondisi cairan dihitung dengan menggunakan flash calculation pada umpan, titik didih dan titik embun umpan sebagai berikut : Trial L (Liquid) $=0,99$ dan V (Vapour) $=0,01($ dilakukan dengan Trial)

Tabel 3.7 Perhitungan Flash Umpan Pada Temperatur Operasi

\begin{tabular}{|c|c|c|c|c|c|}
\hline $\begin{array}{c}\text { Kompo } \\
\text { nen }\end{array}$ & $\mathbf{Z i}$ & $\mathbf{P i}^{*}$ & $\begin{array}{c}\mathbf{K i}= \\
\mathbf{P i} / \mathbf{P} \\
\mathbf{t}\end{array}$ & $\begin{array}{c}\mathbf{X i}= \\
\mathbf{Z i} /(\mathbf{V k i} \\
+\mathbf{L})\end{array}$ & $\begin{array}{c}\mathbf{Y i} \\
\mathbf{Z} \mathbf{Z}(\mathbf{V}+ \\
\mathbf{L} / \mathbf{K i})\end{array}$ \\
\hline $\mathrm{C}_{3}$ & 0,0888 & 16433,18 & 1,212 & 0,089 & 0,109 \\
\hline $\mathrm{C}_{3}{ }^{2}$ & 0,4868 & 19993,95 & 1,475 & 0,484 & 0,725 \\
\hline i- $\mathrm{C}_{4}$ & 0,1374 & 6715,53 & 0,495 & 0,138 & 0,069 \\
\hline n- $\mathrm{C}_{4}$ & 0,0316 & 5167,18 & 0,381 & 0,032 & 0,012 \\
\hline $1+\mathrm{i}-\mathrm{C}_{4}$ & 0,1440 & 6216,41 & 0,459 & 0,145 & 0,067 \\
\hline Tr- i-C 4 & 0,0703 & 5043,60 & 0,372 & 0,071 & 0,026 \\
\hline Cis-C & 0,0411 & 4780,34 & 0,353 & 0,041 & 0,015 \\
\hline & & & & 1,000 & 1,023 \\
\hline
\end{tabular}


Jadi liquid umpan adalah $0,99 \times 1186,19=$ $1174,33 \mathrm{kgmol} / \mathrm{jam}$ dan vapour umpan adalah $0,01 \times 1186,19=11,86 \mathrm{kgmol} / \mathrm{jam}$. Selanjutnya menentukan titik didih umpan dengan Titik Didih $=63,06{ }^{\circ} \mathrm{C}$ (Trial)

Tabel 3.8 Menentukan Titik Didih Umpan

\begin{tabular}{|c|c|c|c|c|c|c|c|}
\hline \multirow{2}{*}{$\begin{array}{c}\text { Komp } \\
\text { onen }\end{array}$} & \multicolumn{3}{|c|}{ Bilangan Antoine } & \multirow{2}{*}{$\mathbf{P i} *$} & \multirow{2}{*}{$\begin{array}{c}\mathbf{K i} \\
= \\
\mathbf{P i} * / \\
\mathbf{P t}\end{array}$} & \multirow{2}{*}{$\mathbf{Z i}$} & \multirow{2}{*}{$\begin{array}{l}Y \mathbf{Y}=\mathbf{Z} \\
\mathbf{i} . \mathrm{Ki}\end{array}$} \\
\hline & $\mathbf{A}$ & B & $\mathrm{C}$ & & & & \\
\hline $\mathrm{C}_{3}$ & $\begin{array}{c}6,81 \\
02\end{array}$ & $\begin{array}{l}805, \\
180\end{array}$ & $\begin{array}{l}246, \\
666\end{array}$ & $\begin{array}{l}1623 \\
8,93\end{array}$ & $\begin{array}{c}1,19 \\
78\end{array}$ & $\begin{array}{c}0,08 \\
88\end{array}$ & 0,106 \\
\hline $\mathrm{C}_{3}=$ & $\begin{array}{c}6,85 \\
46\end{array}$ & $\begin{array}{l}796, \\
074\end{array}$ & $\begin{array}{c}248, \\
063\end{array}$ & $\begin{array}{l}1976 \\
2,35\end{array}$ & $\begin{array}{c}1,45 \\
77\end{array}$ & $\begin{array}{c}0,48 \\
67\end{array}$ & 0,710 \\
\hline i- $\mathrm{C}_{4}$ & $\begin{array}{c}6,76 \\
43\end{array}$ & $\begin{array}{l}895, \\
566\end{array}$ & $\begin{array}{l}241, \\
223\end{array}$ & $\begin{array}{c}6624, \\
134\end{array}$ & $\begin{array}{c}0,48 \\
86\end{array}$ & $\begin{array}{c}0,13 \\
74\end{array}$ & 0,067 \\
\hline $\mathrm{n}-\mathrm{C}_{4}$ & $\begin{array}{c}6,80 \\
84\end{array}$ & $\begin{array}{c}937, \\
107\end{array}$ & $\begin{array}{c}239 \\
095\end{array}$ & $\begin{array}{c}5092, \\
587\end{array}$ & $\begin{array}{c}0,37 \\
56\end{array}$ & $\begin{array}{c}0,03 \\
16\end{array}$ & 0,012 \\
\hline $\begin{array}{c}1+\mathrm{i}- \\
\mathrm{C}_{4}\end{array}$ & $\begin{array}{c}6,84 \\
24\end{array}$ & $\begin{array}{l}926, \\
468\end{array}$ & $\begin{array}{c}240, \\
197\end{array}$ & $\begin{array}{c}6128 \\
315\end{array}$ & $\begin{array}{c}0,45 \\
2\end{array}$ & $\begin{array}{c}0,14 \\
40\end{array}$ & 0,065 \\
\hline $\begin{array}{c}\text { Tr- i- } \\
\mathrm{C}_{4}\end{array}$ & $\begin{array}{c}6,84 \\
19\end{array}$ & $\begin{array}{l}949, \\
613\end{array}$ & $\begin{array}{l}238 \\
829\end{array}$ & $\begin{array}{c}4969 \\
697\end{array}$ & $\begin{array}{c}0,36 \\
66\end{array}$ & $\begin{array}{c}0,07 \\
03\end{array}$ & 0,026 \\
\hline Cis- $\mathrm{C}_{4}$ & $\begin{array}{c}6,90 \\
14\end{array}$ & $\begin{array}{l}972, \\
941\end{array}$ & $\begin{array}{l}238 \\
297\end{array}$ & $\begin{array}{c}4708, \\
332\end{array}$ & $\begin{array}{c}0,34 \\
73\end{array}$ & $\begin{array}{c}0,04 \\
11\end{array}$ & 0,014 \\
\hline & & & & & & & 1,000 \\
\hline
\end{tabular}

Dari tabel diatas, dapat dilihat bahwa hasil dari trial yang tepat untuk titik didih adalah $63,06{ }^{\circ} \mathrm{C}$.

Kemudian menentukan titik embun umpan dengan Titik Embun $=79,22^{\circ} \mathrm{C}$ (Trial)
Tabel 3.9 Menentukan Titik Embun Umpan

\begin{tabular}{|c|c|c|c|c|c|c|c|}
\hline \multirow{2}{*}{$\begin{array}{c}\text { Komp } \\
\text { onen }\end{array}$} & \multicolumn{3}{|c|}{ Bilangan Antoine } & \multirow{2}{*}{$\mathbf{P i}^{*}$} & \multirow{2}{*}{$\begin{array}{c}\mathbf{K i}= \\
\mathbf{P i} / \mathbf{P} \\
\mathbf{t}\end{array}$} & \multirow{2}{*}{$\mathbf{Z i}$} & \multirow{2}{*}{$\begin{array}{l}\mathbf{Z i} / \\
\mathbf{K i}\end{array}$} \\
\hline & $\mathbf{A}$ & B & C & & & & \\
\hline \multirow{2}{*}{$\mathrm{C} 3$} & 6,81 & 805 , & 246 , & 2185 & 1,611 & 0,08 & 0,0 \\
\hline & 02 & 180 & 666 & 0,9 & 784 & 88 & 55 \\
\hline \multirow{2}{*}{$\mathrm{C} 3=$} & 6,85 & 796 , & 248, & 2643 & 1,949 & 0,48 & 0,2 \\
\hline & 46 & 074 & 063 & 4,9 & 917 & 68 & 50 \\
\hline \multirow{2}{*}{ i- $\mathrm{C} 4$} & 6,76 & 895 , & 241, & 9322 & 0,687 & 0,13 & 0,2 \\
\hline & 43 & 566 & 223 & ,99 & 691 & 74 & 00 \\
\hline \multirow{2}{*}{ n- $C 4$} & 6,80 & 937, & 239 , & 7317 & 0,539 & 0,03 & 0,0 \\
\hline & 84 & 107 & 095 & ,94 & 793 & 16 & 58 \\
\hline \multirow{2}{*}{$\begin{array}{c}1+\mathrm{i}- \\
\mathrm{C} 4\end{array}$} & 6,84 & 926 , & 240 , & 8747 & 0,645 & 0,14 & 0,2 \\
\hline & 24 & 468 & 197 & ,89 & 27 & 41 & 23 \\
\hline \multirow{2}{*}{$\begin{array}{c}\text { Tr- i- } \\
\text { C4 }\end{array}$} & 6,84 & 949 , & 238 , & 7180 & 0,529 & 0,07 & 0,1 \\
\hline & 19 & 613 & 829 &, 52 & 656 & 03 & 33 \\
\hline \multirow{3}{*}{ Cis-C4 } & 6,90 & 972 , & 238 , & 6873 & 0,507 & 0,04 & 0,0 \\
\hline & 14 & 941 & 297 &, 58 & 015 & 11 & 81 \\
\hline & & & & & & & $\begin{array}{l}1,0 \\
00\end{array}$ \\
\hline
\end{tabular}

Dari tabel diatas, dapat dilihat bahwa hasil dari trial yang tepat untuk titik embun adalah $79,22^{\circ} \mathrm{C}$

Kemudian dihitung Entalpy berdasarkan kondisi tersebut diatas:

Dimana :

$$
q=\frac{H_{V}-H_{F}}{H_{V}-H_{L}}
$$

$\mathrm{H}_{\mathrm{V}}=$ Entalpy umpan pada titik embunnya

$\mathrm{H}_{\mathrm{L}}=$ Entalpy umpan pada titik didihnya

$\mathrm{H}_{\mathrm{F}}=$ Entalpy umpan pada kondisi saat memasuki kolom

- Tekanan Umpan $=18,43 \mathrm{~kg} / \mathrm{cm}^{2}=261,62$ psia

- Temperatur Titik didih $($ trial $)=63,06{ }^{\circ} \mathrm{C}=$ $145,51^{\circ} \mathrm{F}$

- Temperatur Titik embun (trial) $=79,22^{\circ} \mathrm{C}$ $=174,60^{\circ} \mathrm{F}$

Entalpy total dicari dari grafik GPSA, (Lamp 4 dan 5 ) untuk

- Entalpy Total $\left(\mathrm{H}_{\mathrm{L}}\right)$ pada temperatur titik didih $=29 \mathrm{Btu} / \mathrm{lb}$ 
- Entalpy Total $(\mathrm{Hv})$ pada temperatur titik embun $=176 \mathrm{Btu} / \mathrm{lb}$

- $\quad$ Entalpy Umpan $\left(\mathrm{H}_{\mathrm{F}}\right)=\mathrm{H}_{\mathrm{L}} \mathrm{x}$ mol fraksi cairan $+\mathrm{Hv}_{\mathrm{v}} \mathrm{mol}$ fraksi uap $=29 \mathrm{Btu} / \mathrm{lb} \times 0,99+176 \mathrm{Btu} / \mathrm{lb} \times$

$$
0,01=30,47 \mathrm{Btu} / \mathrm{lb}
$$

$q=\frac{H_{V}-H_{F}}{H_{V}-H_{L}}$

$q=\frac{176-30,47}{176-29}=0,99$ (Terbukti)

Dari perhitungan di atas, Untuk nilai $q=0,99$ terbukti benar sama dengan trial yang digunakan sebelumnya dimana Trial L $($ Liquid $)=0,99$.

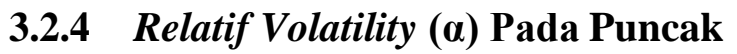

Menghitung Relative Volatility $(\alpha)$ tiap komponen " $i$ “ terhadap komponen kunci berat (i-C4) pada temperatur puncak kolom, umpan, dan temperatur bawah kolom.

Rumus , $\alpha=\frac{K i}{K_{H K}}=\frac{K i}{K_{i-C 4}}$

Temperatur $=48,22{ }^{\circ} \mathrm{C}$

Tekanan $=18,43 \mathrm{~kg} / \mathrm{cm}^{2}=13.556,95 \mathrm{mmHg}$

Tabel 3.10 Perhitungan Relatif Volatility (a) Pada Bagian Atas

\begin{tabular}{|c|c|c|c|c|c|c|}
\hline \multirow{2}{*}{$\begin{array}{c}\text { Komp } \\
\text { onen }\end{array}$} & \multicolumn{3}{|c|}{ Bilangan Antoine } & \multirow{2}{*}{$\mathbf{P i}{ }^{*}$} & \multirow{2}{*}{$\begin{array}{c}\mathbf{K i}= \\
\mathbf{P i} / \mathbf{P t}\end{array}$} & \multirow{2}{*}{$\begin{array}{c}\alpha \mathbf{i}= \\
(\mathrm{Ki} / \mathrm{Khk} \\
)\end{array}$} \\
\hline & $\mathbf{A}$ & B & $\mathbf{C}$ & & & \\
\hline $\mathrm{C}_{3}(\mathrm{lk})$ & $\begin{array}{c}6,81 \\
02\end{array}$ & $\begin{array}{c}805, \\
18\end{array}$ & $\begin{array}{r}246, \\
666\end{array}$ & $\begin{array}{l}1201 \\
5,59\end{array}$ & 0,8863 & 2,567 \\
\hline $\mathrm{C}_{3}=$ & $\begin{array}{c}6,85 \\
46\end{array}$ & $\begin{array}{l}796, \\
074\end{array}$ & $\begin{array}{l}248, \\
063\end{array}$ & $\begin{array}{l}1471 \\
2,73\end{array}$ & 1,0853 & 3,144 \\
\hline $\begin{array}{l}\text { i- } C_{4} \\
\text { (hk) }\end{array}$ & $\begin{array}{c}6,76 \\
43\end{array}$ & $\begin{array}{l}895, \\
566\end{array}$ & $\begin{array}{l}241, \\
223\end{array}$ & $\begin{array}{c}4679, \\
99\end{array}$ & 0,3452 & 1,000 \\
\hline $\mathrm{n}-\mathrm{C}_{4}$ & $\begin{array}{c}6,80 \\
84\end{array}$ & $\begin{array}{c}937, \\
107\end{array}$ & $\begin{array}{l}239, \\
095\end{array}$ & $\begin{array}{c}3521, \\
81\end{array}$ & 0,2598 & 0,753 \\
\hline $\begin{array}{c}1+\mathrm{i}- \\
\mathrm{C}_{4}\end{array}$ & $\begin{array}{c}6,84 \\
24 \\
\end{array}$ & $\begin{array}{c}926, \\
468\end{array}$ & $\begin{array}{c}240, \\
197 \\
\end{array}$ & $\begin{array}{c}4267, \\
42\end{array}$ & 0,3148 & 0,912 \\
\hline $\begin{array}{c}\text { Tr- i- } \\
\mathrm{C}_{4}\end{array}$ & $\begin{array}{c}6,84 \\
19 \\
\end{array}$ & $\begin{array}{r}949, \\
613 \\
\end{array}$ & $\begin{array}{l}238, \\
829 \\
\end{array}$ & $\begin{array}{c}3417, \\
64\end{array}$ & 0,2521 & 0,730 \\
\hline Cis- $\mathrm{C}_{4}$ & $\begin{array}{c}6,90 \\
14\end{array}$ & $\begin{array}{l}972, \\
941\end{array}$ & $\begin{array}{l}238, \\
297\end{array}$ & $\begin{array}{c}3203, \\
80\end{array}$ & 0,2363 & 0,685 \\
\hline
\end{tabular}

Dari tabel diatas, dapat dilihat nilai relative volatility masing masing komponen bagian atas terhadap komponen heavy key, seperti contoh nilai relative volatility $\mathrm{C}_{3}$ adalah 2,567, nilai relative volatility komponen $\mathrm{C}_{3}=$ adalah 3,144 , dan seterusnya.

\subsubsection{Relatif Volatility $(\alpha)$ Pada Bagian} Bawah Kolom

Temperatur $=97,14{ }^{\circ} \mathrm{C}$

Tekanan $\quad=18,55 \mathrm{~kg} / \mathrm{cm}^{2}=13.640,46$ $\mathrm{mmHg}$

Tabel 3.11 Perhitungan Relatif Volatility

\begin{tabular}{|c|c|c|c|c|c|c|}
\hline \multirow{2}{*}{ Komponen } & \multicolumn{3}{|c|}{ Bilangan Antoine } & \multirow{2}{*}{$\mathbf{P i}^{*}$} & $\begin{array}{c}\text { Ki }= \\
\mathbf{P i} / \mathbf{P t}\end{array}$ & $\begin{array}{c}\boldsymbol{\alpha i}= \\
(\mathbf{K i} / \mathbf{K h k})\end{array}$ \\
\cline { 2 - 4 } & A & $\mathbf{B}$ & $\mathbf{C}$ & & 2,1549 & 2,242 \\
\hline C3 (lk) & 6,8102 & 805,18 & 246,666 & 29394,17 & 2,967 \\
\hline C3 $=$ & 6,8546 & 796,074 & 248,063 & 35355,53 & 2,5920 & 2,697 \\
\hline i- C4 (hk) & 6,7643 & 895,566 & 241,223 & 13109,38 & 0,9611 & 1,000 \\
\hline n- C4 & 6,8084 & 937,107 & 239,095 & 10502,78 & 0,7699 & 0,801 \\
\hline 1 + i-C4 & 6,8424 & 926,468 & 240,197 & 12473,75 & 0,9144 & 0,952 \\
\hline Tr- i-C4 & 6,8419 & 949,613 & 238,829 & 10361,54 & 0,7596 & 0,790 \\
\hline Cis-C4 & 6,9014 & 972,941 & 238,297 & 10020,67 & 0,7346 & 0,764 \\
\hline
\end{tabular}

Dari tabel diatas, dapat dilihat nilai relative volatility masing masing komponen bagian bawah terhadap komponen heavy key, seperti contoh nilai relative volatility $\mathrm{C}_{3}$ adalah 2,242, nilai relative volatility komponen $\mathrm{C}_{3}=$ adalah 2,697, dan seterusnya. 
4.2.6 Relatif Volatility (a) Rata-Rata

Tabel 4.12 Perhitungan Relatif Volatility

\begin{tabular}{|c|c|c|c|c|c|}
\hline \multirow{2}{*}{$\begin{array}{c}\text { Komp } \\
\text { onen }\end{array}$} & \multicolumn{2}{|c|}{ Top Kolom } & \multicolumn{2}{|l|}{ Bottom } & \multirow{2}{*}{$\begin{array}{c}\text { (oi) rata- } \\
\text { rata } \\
(\mathrm{A}+\mathrm{B}) / 2\end{array}$} \\
\hline & Ki & $\alpha i(A)$ & $\mathbf{K i}$ & ai (B) & \\
\hline C3 (lk) & 0,8863 & 2,567 & 2,1549 & 2,242 & 2,405 \\
\hline $\mathrm{C} 3=$ & 1,0853 & 3,144 & 2,5919 & 2,697 & 2,920 \\
\hline $\begin{array}{c}\text { i- C4 } \\
\text { (hk) }\end{array}$ & 0,3452 & 1,000 & 0,9611 & 1,000 & 1,000 \\
\hline n- C4 & 0,2598 & 0,753 & 0,7699 & 0,801 & 0,777 \\
\hline $\begin{array}{c}1+\mathrm{i}- \\
\mathrm{C} 4\end{array}$ & 0,3148 & 0,912 & 0,9144 & 0,952 & 0,932 \\
\hline $\begin{array}{c}\text { Tr- i- } \\
\mathrm{C} 4\end{array}$ & 0,2521 & 0,730 & 0,7596 & 0,7906 & 0,760 \\
\hline Cis-C4 & 0,2363 & 0,685 & 0,7346 & 0,764 & 0,724 \\
\hline
\end{tabular}

Dari tabel diatas, dapat dilihat nilai relative volatility masing masing komponen rata- rata terhadap komponen heavy key, seperti contoh nilai relative volatility $\mathrm{C}_{3}$ adalah 2,405 ,

nilai relative volatility komponen $\mathrm{C}_{3}=$ adalah 2,920 , dan seterusnya.

\subsubsection{Faktor Separasi $\left(\mathrm{S}_{\mathrm{F}}\right)$ dan Tray Minimum $\left(\mathbf{S}_{\mathbf{m}}\right)$}

Menghitung Faktor Separasi $\left(\mathrm{S}_{\mathrm{F}}\right)$ dan

Tray Minimum $\left(\mathrm{S}_{\mathrm{m}}\right)$ dengan menggunakan metode Fenske.

- $\left(\mathrm{X}_{\mathrm{D}}\right)_{\mathrm{LK}}=0,1336$ adalah fraksi mol komponen kunci ringan di Distilat (D)

- $\left(\mathrm{X}_{\mathrm{D}}\right)_{\mathrm{HK}}=0,0079$ adalah fraksi mol komponen kunci berat di Distilat (D)

- $\left(\mathrm{X}_{\mathrm{B}}\right)_{\mathrm{LK}}=0,0413$ adalah fraksi mol komponen kunci ringan di Bottom (B)

- $\left(\mathrm{X}_{\mathrm{B}}\right)_{\mathrm{HK}}=0,2750$ adalah fraksi mol komponen kunci berat di Bottom (B)

Separasion Faktor $\left(\mathrm{S}_{\mathrm{F}}\right)=\left(\frac{X_{D}}{X_{B}}\right)_{L K} x\left(\frac{X_{B}}{X_{D}}\right)_{H K}$
Separasion $\quad$ Faktor
$\left(\frac{0,1336}{0,0413}\right) \quad x\left(\frac{0,275}{0,0079}\right)=112,925$

Dengan menggunakan persamaan Fenske yaitu :

$S_{m}=\frac{\log \left\{\left(X_{L K} / X_{H K}\right)_{D} \cdot\left(X_{H K} / X_{L K}\right)_{B}\right\}}{\log \alpha_{a v g}}$

Minimum Tray $\left(\mathrm{S}_{\mathrm{m}}\right)=\frac{\log \{112,925\}}{\log (2,405)}=5,38$ atau 6 tray minimum, artinya tray yang dibutuhkan untuk kolom fraksinasi dengan karakteristik umpan di atas adalah minimal 6 tray.

\subsubsection{Menghitung Harga $\boldsymbol{\theta}$ (Konstanta Underwood)}

Temperatur $=63,68^{\circ} \mathrm{C}$

Tekanan $\quad=18,43 \mathrm{~kg} / \mathrm{cm}^{2}$

Menentukan Konstanta Underwood, $\Theta$ dengan rumus :

$\frac{\sum\left(\alpha_{\text {iavg }} * X_{i} D\right)}{\sum\left(\alpha_{\text {iavg }}-\right)}=1-q$

Karena umpan adalah fase campuran cair dan uap, maka $\mathrm{q}=0,99$

$\frac{\sum\left(\alpha_{\text {iavg }} * \mathrm{X}_{\mathrm{i}} \mathrm{D}\right)}{\sum\left(\alpha_{\text {iavg }}\right)}=1-\mathrm{q}$ maka

$\frac{\sum\left(\alpha_{\text {iavg }} * \mathrm{X}_{\mathrm{i}} \mathrm{D}\right)}{\sum\left(\alpha_{\text {iavg }}-\right)}=1-0,99=0,01$ dengan trial

, maka didapat $\Theta=1,289$

\subsubsection{Menentukan Refluks Minimum}

Perhitungan refluks minimum dapat dilihat pada Tabel 4.14 dengan menggunakan nilai $\Theta=1,289$ sebagai berikut. 
Tabel 3.14 Refluks Minimum

\begin{tabular}{|c|c|c|c|c|c|}
\hline \multirow[b]{2}{*}{ Komponen } & \multirow{2}{*}{$\begin{array}{c}\text { Fraksi } \\
\text { Mol } \\
\text { Distilat } \\
\text { (Xi)D }\end{array}$} & \multicolumn{4}{|c|}{$\theta=1,289$} \\
\hline & & $\begin{array}{l}\text { (ai) } \\
\text { avg }\end{array}$ & $\begin{array}{l}(\mathbf{X i}) \mathbf{D} \\
{ }^{*}(\alpha \mathbf{\alpha}) \mathbf{a v} \\
\mathbf{g}\end{array}$ & $\begin{array}{l}(\alpha i) \operatorname{avg} \\
-\theta\end{array}$ & $\begin{array}{l}(\mathrm{Xi}) D^{*}(\alpha \mathrm{i} \\
) \operatorname{avg} /(\alpha \mathrm{i}) \\
\operatorname{avg}-\theta\end{array}$ \\
\hline $\mathrm{C}_{3}(\mathrm{Lk})$ & 0,1336 & 2,405 & 0,3213 & 1,1158 & 0,2879 \\
\hline $\mathrm{C}_{3}=$ & 0,8556 & 2,920 & 2,4987 & 1,6314 & 1,5317 \\
\hline i- $\mathrm{C}_{4}(\mathrm{Hk})$ & 0,0079 & 1,000 & 0,0079 & $-0,2890$ & $-0,0274$ \\
\hline n- $C_{4}$ & 0,0006 & 0,932 & 0,0006 & $-0,3573$ & $-0,0016$ \\
\hline $1+\mathrm{i}-\mathrm{C}_{4}$ & 0,0023 & 0,760 & 0,0017 & $-0,5287$ & $-0,0033$ \\
\hline Total & 1 & & & $\mathrm{Rm}+1$ & 1,7874 \\
\hline
\end{tabular}

Dengan menggunakan persamaan

$: R$ minimum $-1=\sum \frac{((\mathrm{Xi}) \mathrm{D} *(\alpha \mathrm{i}) \mathrm{avg})}{(\alpha \mathrm{i}) \text { avg }-\theta}$

Maka refluks minimum,$R$ minimum $-1=$ 1,7874

Rminimum

$(\mathrm{Rm})=1,7874-1=0,7874$

\subsubsection{Refluks Operasi}

Perhitungan Refluks Operasi dapat dilihat pada tabel 4.15 dengan menggunakan Nilai refluks minimum yang sudah diperoleh sebagai berikut.

Tabel 3.15 Laju Alir Umpan

\begin{tabular}{|l|r|}
\hline Laju Alir & Kgmol/jam \\
\hline Umpan ,F & 1186,19 \\
\hline Produk Bawah, B & 575,23 \\
\hline Produk Atas, D & 610,96 \\
\hline Refluk, L & 1166,67 \\
\hline
\end{tabular}

Rops $=\left(\frac{L}{D}\right)=\left(\frac{1166,67}{610,96}\right)=1,91$

\subsubsection{Jumlah Tray Teoritis}

Untuk menentukan jumlah tray teoritis dengan menggunakan Grafik Gilliland, dengan perhitungan sbb:

$$
\begin{aligned}
& \frac{R_{\text {ops }}-R_{\min }}{R_{\text {ops }}+1}=\frac{1,91-0,7874}{1,91+1}=0,386 \\
& \frac{N-N_{m}}{N+1}=0,283 ; \mathrm{Nm}=6
\end{aligned}
$$

$\mathrm{N}=8,76=9$ buah

Dari Grafik Gilliland (lampiran) didapat jumlah tray secara teori yang dibutuhkan adalah 9 buah.

\subsubsection{Efisiensi Tray}

Efisiensi Tray $=\frac{\text { Tray teoritis }}{\text { Tray Aktual }} \times 100 \%$

$$
=\frac{9}{38} \times 100 \%=23,68 \%
$$

Hal ini berarti, penggunaan jumlah tray pada kolom fraksinasi kurang efisien, karena jumlah tray yang terpasang adalah sebanyak 38 tray sedangkan tray yang dibutuhkan secara teoritis hanya 9 tray.

\section{PENUTUP}

\subsection{Simpulan}

Dari analisa data dan hasil perhitungan penentuan kondisi operasi optimal proses fraksinasi pada Kolom Fraksinasi, dapat disimpulkan:

1) Hasil perhitungan evaluasi kolom berdasarkan data rata-rata adalah sebagai berikut :

a) Kadar kemurnian campuran $\mathrm{C}_{3}$ pada produk puncak sebesar 98,92\%.

b) Kadar kemurnian campuran $\mathrm{C}_{4}$ pada produk bottom sebesar 86,27\%.

2) Variabel proses yang memiliki pengaruh yang signifikan terhadap perubahan kemurnian persen volume $\mathrm{C}_{3}$ dan kemurnian persen volume $\mathrm{C}_{4}$ adalah temperatur bottom kolom dan jumlah refluks . 
3) Peningkatan temperatur bottom kolom dan jumlah refluks akan menyebabkan peningkatan kadar kemurnian campuran $\mathrm{C}_{3}$ dan juga kadar kemurnian campuran $\mathrm{C}_{4}$. Fungsi objektif yang terbentuk dari hasil analisis regresi kedua variabel proses tersebut terhadap parameter optimalisasi adalah sebagai berikut :

$$
\begin{aligned}
& Y_{1}=90,933+0,068 X_{4}+0,028 X_{6} \\
& Y_{2}=14,250+0,667 X_{4}+0,174 X_{6}
\end{aligned}
$$

4) Kondisi optimal yang diperoleh melalui penentuan feasible region dengan cara memplotkan semua fungsi objektif dan juga fungsi kendala yang ada yaitu temperatur bottom kolom $\left(\mathrm{X}_{4}\right)$ sebesar $108,04{ }^{\circ} \mathrm{C}$ dan jumlah refluks $\left(\mathrm{X}_{6}\right)$ sebesar 61,44 ton/jam dengan hasil optimalisasi sebagai berikut:

a) kadar kemurnian campuran $\mathrm{C}_{3}$ pada produk puncak sebesar 99,99\%.

b) kadar kemurnian campuran $\mathrm{C}_{4}$ pada produk bottom sebesar 97,00 \% .

5) Dari perhitungan keekonomian pada kondisi optimal akan diperoleh keuntungan sebesar Rp 44.346.666 /hari atau sebesar Rp 1.330.399.980/bulan

\subsection{Saran}

Agar diperoleh hasil yang lebih optimal pada saat Kolom Fraksinasi memisahkan antara campuran $\mathrm{C}_{3}$ dan campuran $\mathrm{C}_{4}$, hal-hal yang perlu dilakukan adalah:

1) Mengupayakan untuk menaikkan atau menjaga temeperatur bottom kolom pada temperatur sekitar $109{ }^{\circ} \mathrm{C}$ dengan cara menambah aliran Heavy Naphta yang digunakan sebagai pemanas pada reboiler, secara perlahan dan bertahap.

2) Menaikkan atau menjaga temperatur operasi top kolom sekitar $49{ }^{\circ} \mathrm{C}$ dengan cara mengatur jumlah aliran refluks yang dialirkan masuk ke kolom fraksinasi, bila perlu control valve yang mengatur aliran dimanualkan untuk memudahkan pengaturan dalam mempertahankan jumlah refluks sehingga kontak antara gas dan cairan akan maksimal dan beban kerja reboiler juga tidak terlalu berat.

\section{DAFTAR PUSTAKA}

Budi, Triton Prawira, 2006, "SPSS 13.0 Terapan; Riset Statistik Parametrik", Andi, Yogyakarta.

Christie.J, Geankoplis, 1983, "Transport Process And Unit Operation". Allyn And Bacon, Inc, London.

Gabrys, Bogdan et all., 2006, "KnowledgeBased Intelligent Information and Engineering Systems $10^{\text {th }}$ Edition, Springer, UK.

Kardjono, SA, 2003, "Petroleum Refining Process". Pusat Pendidikan dan Pelatihan Minyak dan Gas Bumi, Cepu.

Kardjono, SA, 2001, "Produk Migas-III". Pusat Pendidikan dan Pelatihan Minyak dan Gas Bumi, Cepu.

Nelson, W.L. 1958, "Petroleum Refinery Engineering”, New York:McGrawHill Book Company, New York. 
Syahrial, Gunandar, 2005, "Penelitian Operasional I". Universitas Tulang Bawang Lampung, Bandar Lampung.

Winkle, Matthew Van, 1967, "Distillation", McGraw-Hill Book Company, New York. 